\title{
Inuvialuit knowledge of Pacific salmon range expansion in the western Canadian Arctic
}

\author{
Zander Chila, Karen M. Dunmall, Tracey A. Proverbs, Trevor C. Lantz, Aklavik Hunters and Trappers \\ Committee, Inuvik Hunters and Trappers Committee, Sachs Harbour Hunters and Trappers Committee, \\ Olokhaktomiut Hunters and Trappers Committee, and Paulatuk Hunters and Trappers Committee
}

\begin{abstract}
Rapid climate change is altering Arctic ecosystems and significantly affecting the livelihoods and cultural traditions of Arctic Indigenous peoples. In the Inuvialuit Settlement Region (ISR), growing evidence suggests that climate change is altering marine environments. In this project we recorded and synthesized Inuvialuit knowledge of Pacific salmon. We used methods that are emergent in fisheries science to combine interview information with voluntary harvest data and better understand changes to salmon in the Arctic. We conducted 53 interviews with Inuvialuit fishers about the history of Pacific salmon harvest, how it has changed in recent decades, and concurrent changes to local environments and fish species. Our interviews show that historical, incidental salmon harvest in the ISR ranged from infrequent to common among western communities, but was rare or unprecedented among eastern communities. Participants in all six communities reported a recent increase in salmon harvest and attributed this shift to regional environmental change. Fishers were concerned that salmon would negatively affect their cultural traditions and preferred fish species. Given uncertainty about the effects of salmon on local fisheries, research on salmon in the Arctic, the likelihood of their establishment, and their potential to provide subsidies to Arctic freshwater ecosystems is vital.

Résumé : Les changements climatiques rapides modifient les écosystèmes arctiques et ont une importante incidence sur les moyens de subsistance et les traditions culturelles des peuples autochtones de l'Arctique. Dans la région désignée des Inuvialuit (RDI), un corpus croissant de données indiquerait que les changements climatiques modifient les milieux marins. Nous avons enregistré et synthétisé les connaissances des Inuvialuit sur les saumons du Pacifique. Nous avons utilisé de méthodes émergentes en sciences halieutiques afin de combiner de l'information tirée d'entrevues à des données sur les prises fournies sur une base volontaire et de mieux comprendre les changements touchant aux saumons dans l'Arctique. Nous avons réalisé 53 entrevues avec des pêcheurs inuvialuits sur l'histoire de la pêche aux saumons du Pacifique, ses changements au cours des dernières décennies et les modifications concurrentes subies par les milieux et espèces de poissons de la région. Les entrevues montrent que les prises accessoires passées de saumons dans la RDI sont peu fréquentes à répandues dans les communautés de l'Ouest, mais rares à inexistantes dans les communautés de l'Est. Des participants dans les six communautés ont relevé une augmentation récente des prises de saumons et ont attribué ce changement à des changements environnementaux régionaux. Les pêcheurs se sont dits inquiets de l'impact potentiellement négatif des saumons sur leurs traditions culturelles et sur leurs espèces de poissons de prédilection. Étant donné l'incertitude quant aux effets des saumons sur les pêches locales, la recherche sur les saumons dans l'Arctique, sur la probabilité de leur établissement et sur le potentiel qu'ils ont de fournir des subsides aux écosystèmes d'eau douce arctiques est d'importance capitale. [Traduit par la Rédaction]
\end{abstract}

\section{Introduction}

Accelerated rates of warming in Arctic regions have put circumpolar communities on the front lines of the climate crisis (Ford et al. 2014; Krupnik et al. 2010; NOAA 2017; Pearce et al. 2015). In the western Arctic of what is now called Canada, the cultural traditions and livelihoods of Inuvialuit are strongly linked to the terrestrial and aquatic ecosystems (Alunik et al. 2003). Over the last 150 years, Inuvialuit lifeways have faced repeated change with the arrival of whalers, traders, and missionaries, disease epidemics, and the institution of colonial policies and economies (Alunik et al. 2003; Usher 2002).

Like many Arctic peoples, Inuvialuit communities now face rapid environmental shifts that are altering aquatic and terrestrial ecosystems and the distributions of species with cultural and subsistence importance (Ford et al. 2014; Krupnik et al. 2010; Pearce et al. 2015). The primary drivers of these changes include anthropogenic climate warming (IPCC 2019), sea ice loss (Krupnik et al. 2010), permafrost thaw (Lantz and Kokelj 2008), vegetation change (Chen et al. 2021), and

Received 21 June 2021. Accepted 9 November 2021.

Z. Chila, T.A. Proverbs, and T.C. Lantz. University of Victoria, School of Environmental Studies, Victoria, B.C., Canada.

K.M. Dunmall. Fisheries and Oceans Canada, Winnipeg, Man., Canada.

Aklavik Hunters and Trappers Committee. Aklavik, N.T., Canada.

Inuvik Hunters and Trappers Committee. Inuvik, N.T., Canada.

Sachs Harbour Hunters and Trappers Committee. Sachs Harbour, N.T., Canada.

Olokhaktomiut Hunters and Trappers Committee. Ulukhaktok, N.T., Canada.

Paulatuk Hunters and Trappers Committee. Paulatuk, N.T., Canada.

Corresponding author: Trevor Lantz (email: tlantz@uvic.ca).

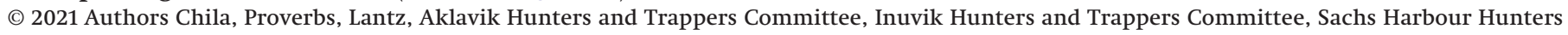

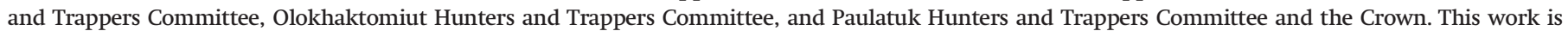

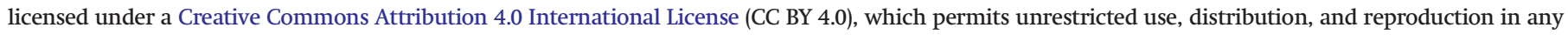
medium, provided the original author(s) and source are credited. 
Fig. 1. Left: map of the current and limited distribution of Pacific salmon (Oncorhynchus spp.). Distribution data adapted from Augerot and Foley 2005. Right: map of the six communities in the Inuvialuit Settlement Region. The red box in the left map panel represents the area displayed in the right map panel. Basemap data from https://public.opendatasoft.com/explore/dataset/world-administrative-boundaries/. Projection: NAD83(CSRS).

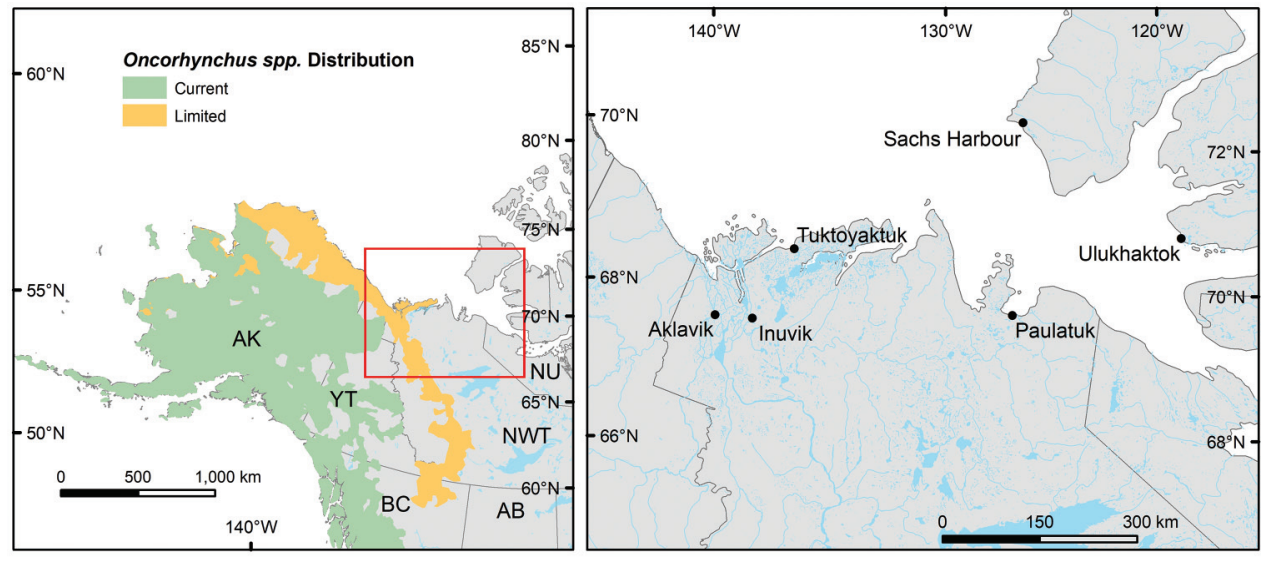

altered weather conditions (Bintanja and Andry 2017; Walsh et al. 2011). These environmental changes are also facilitating the range expansion of southern species into Arctic environments (NOAA 2017; Tape et al. 2016, 2018). The combined effects of these changes will have significant impacts on Inuvialuit lifeways (Alunik et al. 2003; IRC 2018).

In the last several decades there has been growing recognition that Indigenous knowledge is vital to many fields of research (Grenier 1998; Inglis 1993; Johannes 1989; Linden 1991; Wenzel 1999). Indigenous knowledge systems are making key contributions to fields such as zoology, botany, climate science, oceanography, conservation science, and anthropology (Drew 2005; Reid et al. 2021; Smith 1999; Smith and Sharp 2012; Turner et al. 2000; Usher 2002). The importance of Indigenous knowledge is now recognized by various levels of government, from local-scale wildlife management to federal policy (Usher 2002; Houde 2007). In many jurisdictions it has become a requirement to consider Indigenous Knowledge (IK) in decision-making processes (Usher 2002; Houde 2007). The holistic nature and temporal depth of IK make it an important source of insight into the environmental changes facing Inuit communities. IK is increasingly being used to document changes in species distributions and abundance and understand the ecological and sociocultural implications of those changes (Lima et al. 2017; Lopes et al. 2018). This application has yet to be widely considered in fisheries contexts (Cooke et al. 2021), but can advance our understanding of the rapid environmental changes that are influencing fisheries.

Understanding the northward expansion of Pacific salmon (Oncorhynchus spp.) into the Inuvialuit Settlement Region (ISR; Fig. 1) is an example of where IK can make a significant contribution. The five species of Pacific salmon (Onchorynchus spp.) in North America have highly diverse life-history traits and strategies (Groot 1991, 2010; Qin and Kaeriyama 2016), likely a product of their successful diversification in response to dramatic changes in topography, glaciations, and climate of the west coast of North America over the last five million years (Montgomery 2000; Waples et al. 2008). Life history models suggest that chum salmon (Onchorynchus keta) and pink salmon (Onchorynchus gorbuscha) are most likely to expand their range into the warming Arctic, but standard methods for measuring range expansion are made difficult by the climate and vast, remote geography of the Arctic (Carothers et al. 2019; Farley et al. 2020; Dunmall et al. 2013, 2018; Nielsen et al. 2013). These challenges can be overcome by using interdisciplinary methods and the combination of Inuvialuit knowledge and voluntary harvest data.

Inuvialuit harvesters are concerned about salmon range shifts and the potential for salmon to prey on or outcompete subsistence fish, such as iqalukpik (Arctic char, Salvelinus alpinus) and anaaktiq (broad whitefish, Coregonus nasus) (Alunik et al. 2003; Krupnik et al. 2010; Pearce et al. 2015). Salmon impacts on local fish are likely to affect Inuvialuit lifeways because fishing is an integral part of Inuvialuit culture (Alunik et al. 2003; Carothers et al. 2019; Dunmall et al. 2016; Dunmall et al. 2018). The importance of these "country" foods goes far beyond subsistence. They are critical to individual and community health, well-being, and cultural identity (Alunik et al. 2003; Kuhnlein and Receveur 1996; Proverbs et al. 2020). As such, the northward expansion of salmon is also likely to influence sociocultural and socioeconomic processes. To evaluate the risks and opportunities salmon pose to Inuvialuit communities and Arctic fish populations, we must first understand salmon abundance and spatial distributions and how these have changed in recent decades. Detailed knowledge held by Inuvialuit fishers provides an essential source of insight on salmon ranges in the Arctic, how they have changed in recent decades, and the sociocultural context of shifting species ranges. Knowing that Inuvialuit harvesters hold this information, the Fisheries Joint Management Committee, an Inuvialuit - Fisheries and Oceans Canada (DFO) co-management body, requested an Inuvialuit knowledge project be done to understand the historical and changing state of salmon in the ISR. In this research project we documented the following: (1) changes in the magnitude of salmon harvest over the last four decades, (2) co-occurring changes in local fish populations attributed to increasing salmon, and (3) environmental factors influencing salmon range expansions. This work is part of the larger Arctic Salmon Project (ASP; Dunmall et al. 2018), which has the goal of understanding the changing harvest of salmon in Arctic Canada. This paper synthesizes Inuvialuit knowledge to provide historical context on the diversity and distribution of Pacific salmon in the nearshore and freshwater environments of the ISR. This context is a necessary foundation for future studies that focus specifically on the sociocultural dimension of these changes. Together, this research may inform management, mitigation, and policy that addresses species range shifts that may affect Inuvialuit cultural activities.

\section{Study background}

This research project is based in the ISR (Fig.1). Historically, Inuvialuit moved throughout their territory to harvest qilalukkat (beluga, Delphinapterus leucas), tuktuvialuit (caribou, Rangifer tarandus), omingmak (muskox, Ovibos moschatus), and diverse fishes and gathered in large numbers for hunts and celebrations (Alunik et al. 2003). Ancestors of the Inuvialuit have lived in this area for over a thousand years (Alunik et al. 2003), and access to cultural practices is an integral component of Inuvialuit identity and well-being (Alunik et al. 2003). There are three dialects of 
Inuvialuktun in the ISR: Sallirmiutun, Uummarmiutun, and Kangiryuarmiutun, and Inuvialuit share many cultural and relational ties to Inuit throughout the Arctic.

As elsewhere throughout the Americas, Euro-American settlers brought colonial worldviews and practices to the ISR in the early 1800s. Exploitative trading operations were common, beginning with the harvest of bowhead whales (Balaena mysticetus) in the late 1800s, then transitioning into the longer fur trade era. These settler industries led to rapid socioeconomic change supported by anti-Indigenous racist policy (Cameron 2012).

In 1984, the history and importance of Inuvialuit ties to the land were recognized by the Canadian government with the signing of the Inuvialuit Final Agreement (IFA) (Government of Canada 1984). Among other things, the IFA established the legal methods by which Inuvialuit govern the ISR under colonial law and Inuvialuit governing organizations. Some of these organizations include the Inuvialuit Game Council (IGC) and the Hunters and Trappers Committees (HTCs) in each community. Inuvialuit organizations also work with federal and territorial governments through co-management bodies such as the Fisheries Joint Management Committee (FJMC) to advise the relevant Ministers regarding the management of marine and terrestrial environments in the ISR and to ensure that resource management relies on Inuvialuit knowledge and worldviews (Binder and Hanbidge 1993).

The ISR has six permanent communities: Aklavik, Inuvik, Paulatuk, Sachs Harbour, Tuktoyaktuk, and Ulukhaktok. Locally, Aklavik, Inuvik, and Tuktoyaktuk are known as the Delta communities, as they are located in or near the fresh or brackish water ecosystems of Mackenzie River delta and estuary. All three of these communities are located near the treeline ecotone where a warmer climate supports more productive woodland and tundra ecosystems (ECG 2009, 2012). Paulatuk, Sachs Harbour, and Ulukhaktok are known as the Outer communities. They are in the eastern ISR and experience a colder climate, are surrounded by less productive tundra ecosystems, and have reduced access to freshwater ecosystems (ECG 2013). The ecological differences between Delta and Outer regions of the ISR are reflected in the subsistence opportunities and preferences of each community. Detailed information on each community's fishing activities, fish preferences, and unique management priorities can be found in their Community Conservation Plans (AHTC et al. 2016; IHTC et al. 2016; OHTC et al. 2016; PHTC et al. 2016; SHHTC et al. 2016; THTC et al. 2016).

\section{Author positionality}

The authorship team is composed of both settler and Indigenous experts. Z.C., K.D., and T.L. are white, settler scholars, and T.P. is a scholar of Kaska-Dena, European, and Bajan descent, all of whom live outside of the ISR. The community HTCs are composed of Inuvialuit harvesters elected by the community, whose mandate includes engaging in "conservation, research, and management" in their regions of the ISR (Government of Canada 1984; p. 30). Z.C., K.D., T.P., and T.L. have worked to temper their positionalities through self-reflection, ongoing development of relationships, continual reporting of results to communities, and earnestly seeking community feedback on their contributions.

\section{Methods}

This project was developed at the request of the FJMC and IGC and was completed through a partnership among the six HTCs, University of Victoria researchers, and DFO. We followed a community-based participatory research methodology (CBPR; Castleden et al. 2012), which increases the knowledge of all parties by equitably involving community members and organizations at all stages of the research process. Iterative stages of input from communities and the primary research team shape the methods, analysis, and interpretation of the research (Castleden et al. 2012). Our research demonstrated the tenets of CBPR by co-developing interview questions, jointly conducting interviews, and validating results with each HTC. We also engaged the communities at large through open houses and dinners where we answered questions about the project. We also reported our results through popular social media.

Our interview questions explored temporal and spatial variation in the harvest of Pacific salmon, historical harvests of Arctic fish species, and the changes in the coastal and freshwater conditions that influence fish populations (Appendix A). Questions that focused on changes in coastal and freshwater conditions varied between communities because of their different environments. Asking slightly different questions among communities positioned us to more accurately understand the changes being experienced by Inuvialuit fishers in different locations. The semistructured nature of the interviews provided participants the opportunity to direct the conversation, and participants each had the opportunity to review their transcript for inaccuracies.

From September 2018 to September 2019, Z.C., T.P., and local interview technicians conducted eight to nine interviews in each Inuvialuit community (total of 53). Local interviewers were hired by the HTC and chose not to be identified in this publication. Interview participants were selected by the HTC based on their knowledge of local fisheries, environmental change, and the history of salmon harvest in the area. Participants were all Inuvialuit and included men and women who ranged in age from approximately 30 to approximately 85 . Each provided informed consent prior to participating in their interview following a protocol approved by the University of Victoria Human Ethics Research Board (application 19-0101). Participants also indicated whether they wanted to be credited by name for their contributions in this paper. Many had lived their whole lives in the community in which we interviewed them, and some had moved between communities and spoke to historical harvests in multiple locations in different years. With one exception, all interviews were conducted in English. One elder chose to do their interview in Kangiryuarmiutun, so we hired a local translator to facilitate the interview and our interactions. While visiting communities, we also hosted open houses where community members could come to learn about this project and provide their input over a shared meal. These were advertised variously on community posting boards, local radio, and HTC Facebook pages. They ranged in attendance from approximately 1530 fishers. While no formal data collection occurred in these settings, they provided visiting members of the research team with context of community perceptions of salmon and their implications. They also facilitated deeper relationships between visiting researchers and local fishers.

Z.C. coded and analyzed interview transcripts with a combination of inductive and deductive approaches using NVivo software (version 10). In the first round of deductive coding, Z.C. reviewed the text of each interview to highlight themes that were identified as important by the IGC and FJMC, such as (1) salmon, (2) local fish species, (3) environmental change, and (4) fishing experience. In further rounds of coding, Z.C. refined these categories into codes designed to answer questions posed by the research team and partner organizations (stated in the Introduction). Further rounds of coding followed an inductive, grounded theory approach. Three additional themes arose from the inductive approach: (1) Inuvialuit culture, (2) access to fishing, and (3) changes in local mammal populations. A total of 145 codes were nested within seven thematic categories (Appendix B, Table B1). The most common thematic category "salmon" focused on several dimensions of the salmon harvest, such as (1) the estimated catch over a fisher's lifetime, (2) the timing and location of catch, and (3) methods of salmon harvests. Other thematic categories included changes to local fish populations and changes to the aquatic environments that may influence or be influenced by salmon presence.

The identification of Pacific salmon to the level of species is a new skill for many Inuvialuit fishers. Even in locations where salmon have been caught for generations, identification skills are limited because historical harvests were predominantly composed 
Fig. 2. Number of participants across all six communities who recalled catching salmon in a given decade compared to the number of participants interviewed $(n=53)$ that were fishing in that decade. The red triangles and red line show the number of salmon that were returned to the Arctic Salmon Project in the last two decades and are plotted on a second, $\log$-scaled $y$ axis.

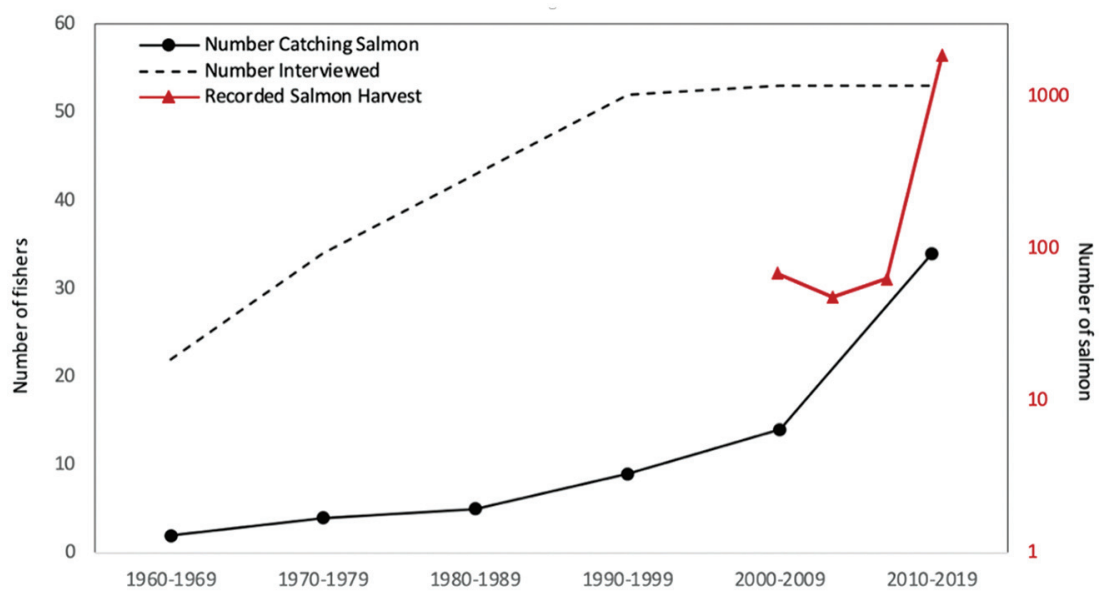

Table 1. Summary data showing whether participants' elders had caught salmon and if the participants themselves had caught salmon.

\begin{tabular}{|c|c|c|c|c|c|}
\hline \multirow[b]{2}{*}{ Community } & \multicolumn{3}{|c|}{ Elders caught salmon } & \multicolumn{2}{|c|}{$\begin{array}{l}\text { Participants } \\
\text { caught salmon }\end{array}$} \\
\hline & Yes & Maybe & No & Yes & No \\
\hline Aklavik $(n=10)$ & 5 & 3 & 2 & 9 & 1 \\
\hline Inuvik ( $n=9)$ & 2 & 1 & 6 & 6 & 3 \\
\hline Tuktoyaktuk $(n=8)$ & 2 & 1 & 5 & 8 & 0 \\
\hline Sachs Harbour $(n=8)$ & 0 & 0 & 8 & 5 & 3 \\
\hline Ulukhaktok $(n=9)$ & 0 & 1 & 8 & 9 & 0 \\
\hline Paulatuk $(n=9)$ & 0 & 0 & 9 & 6 & 3 \\
\hline Total $(n=53)$ & 9 & 6 & 38 & 43 & 10 \\
\hline
\end{tabular}

Note: In this context, we define elders as parents, grandparents, or other community figures who passed important knowledge of fisheries to the interview participants.

of only one species (chum salmon, 0 . keta). Some fishers mentioned that their elders may have had an Inuvialuktun word for salmon, but none knew that word or could confirm its existence. To facilitate conversations about species identification, we brought an identification guide with images and descriptions of each species in both silver and spawning phases and asked individuals to identify the salmon species they had caught. Despite the guide, many fishers remained unsure about species identification, especially if the fish they were trying to identify had been caught years or decades prior. While identification of salmon species proved challenging, fishers were unsurprisingly adept at distinguishing between salmon and local fish species. Throughout this paper, references to salmon (Oncorhynchus spp.) will therefore include all five species of Pacific salmon in North America with an understanding that chum $(0$. keta) and pink $(0$. gorbuscha) are the most common in the ISR, followed by sockeye $(0$. nerka), then Chinook (0. tshawytscha), and finally coho (0. kisutch) (Dunmall et al. 2018; Stephenson 2006).

In this paper, we present the information from the interviews alongside harvest data from the ASP. In the 1990s, DFO began tracking novel salmon occurrences throughout the Arctic when concerned fishers submitted these unknown fish for identification (Babaluk et al. 2000). Around the year 2000, the numbers of salmon being returned began to increase, which prompted a more concerted effort to collect salmon that would become the
ASP. The ASP continues to rely on fishers who submit the entire body or the head of a salmon that they caught to their local management office. Fishers are compensated for their contribution with a gift card for the local grocery store, and the salmon are sent to the ASP research team at DFO. Over the last two decades the ASP has received thousands of observations, monitoring relative salmon abundance across the Canadian Arctic. It is important to note that the voluntary nature of the fish collection means that the number of fish returned to the ASP does not precisely represent salmon abundance. However, in this study we combine information from interviews with fishers and the ASP data to better interpret real changes in salmon harvest. While common in other disciplines, methods such as ours are still emergent in fisheries science (Cooke et al. 2021).

\section{Results}

The interviews we conducted indicate that prior to the $1990 \mathrm{~s}$, salmon catches were rare or unheard of in the Outer communities of Paulatuk, Sachs Harbour, and Ulukhaktok, but had occurred infrequently in the Delta communities of Aklavik, Inuvik, and Tuktoyaktuk for at least the last two generations, or over 60 years (Table 1). Our interviews also show that salmon harvest has increased in all communities in the last 30 years (Fig. 2). Of the 53 Inuvialuit fishers that we interviewed across the ISR, over $80 \%$ had personally caught salmon (Table 1). Among this group, more than $70 \%$ were confident that their parents or grandparents had never caught salmon. All of the fishers who confidently remember their elders catching salmon (approximately 25\%) were from Delta communities.

Of the 53 participants we spoke with, 25 said that in recent years the salmon harvest has been increasing over the last 30 years, three said it was stable, one said it was decreasing, and the other 24 expressed uncertainty about the trend. There were no notable differences between communities in the trends reported. Participants explained that they were hesitant to describe the trends in salmon harvest in certain terms because of high interannual variability in salmon harvest and their limited knowledge of salmon life history. Fishers told us that they wanted to learn more about salmon and indicated that they did not possess the knowledge of salmon habitat, diet, or life history that they did for other fishes. It is noteworthy that fishers felt more confident discussing the population dynamics of important food species such as whitefish, Arctic char, Dolly Varden (Salvelinus malma), and lake trout (Salvelinus namaycush). 
Fig. 3. Number of participants who recalled catching salmon in a given decade compared to the number of participants interviewed that were fishing in that decade. Each panel represents the participants from one Inuvialuit community. The red triangles and red line show the number of salmon returned to the Arctic Salmon Project in the last two decades and are plotted on the on the second $y$ axis.
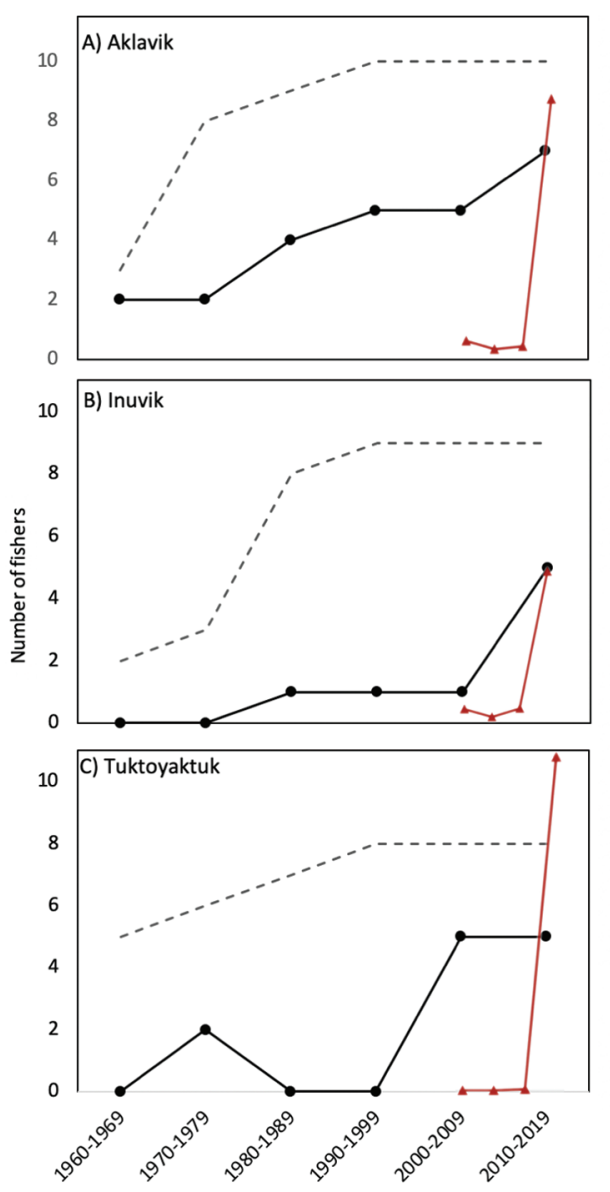

\section{Delta communities}

Interviews showed that fishers in the Delta communities (Aklavik, Tuktoyaktuk, and Inuvik) have been catching salmon longer than those in the Outer communities (Sachs Harbour, Ulukhaktok, and Paulatuk). Participants from Aklavik were clear that people in this community have been catching salmon for generations. Many older participants spoke of their parents or grandparents catching salmon regularly in the Mackenzie Delta. William Storr noted that "people used to catch a lot of salmon actually". He suggested that salmon catches were larger in the past, had decreased in the interim, and were now increasing again. Descriptions of cyclical wildlife population abundances were common throughout the interviews, but this was the only mention of salmon abundance following a similar, multi-decadal cycle.

All but one participant in Aklavik reported catching salmon themselves, and many indicated that they have been catching salmon since before they can remember. In some cases, fishers also made reference to specifically targeting salmon in their fishing activities. Explaining why she hadn't caught salmon that year, Nellie Arey said it was because "we never fish[ed] where we used to fish for salmon". Outside of Aklavik, none of the fishers we interviewed reported targeting salmon, and no one had experienced catching them for as long as they could remember.

In Inuvik and Tuktoyaktuk, only three participants in each community recalled their elders speaking of catching salmon. These participants remember their elders only ever catching a

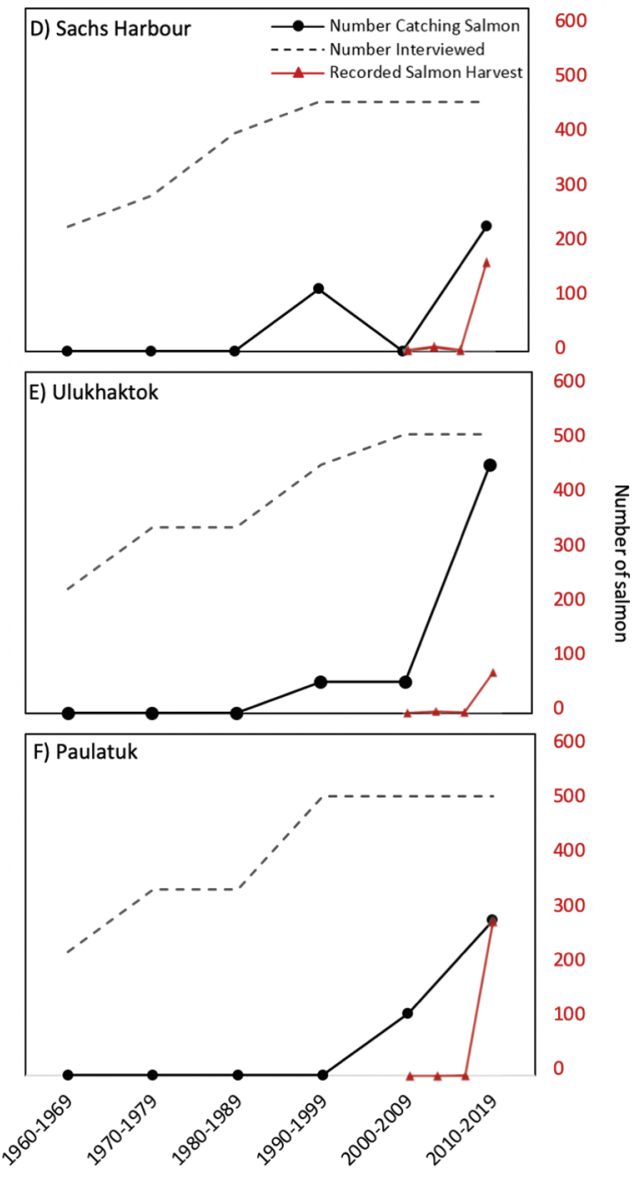

few, and these accounts do not date back as far as those from Aklavik. The earliest accounts of interviewees catching salmon in Tuktoyaktuk and Inuvik are from the late 1970s and early 1980s, respectively. The participants who reported these catches both had elders who had caught salmon before them. In the last decade (2010-2019), all three communities in the Delta region saw an increase in the number of harvesters catching salmon and the number of fish returned to the ASP (Figs. 3A, 3B, 3C).

\section{Outer communities}

In the Outer communities of Sachs Harbour, Ulukhaktok, and Paulatuk, no participants confidently remembered their elders ever catching salmon. In Sachs Harbour, Lena Wolki told us "We never used to have salmon here". Across all three communities the consensus was that semi-regular salmon harvest began between the late 1990s and early 2000s. Fishers in Ulukhaktok noted the possibility that sporadic salmon harvests may have begun as early as the 1970s, but did not identify a specific instance of salmon harvest occurring before the 1990s. In Sachs Harbour and Paulatuk, none of the participants knew of any salmon harvests by their elders or others in the community that predated those described in our interviews.

In Sachs Harbour, the earliest account we heard of salmon being caught was in the 1990s in the harbour in front of town. Another interview participant shared a second account of salmon harvest around this time, but after this event there were no accounts of salmon harvest until the mid-2000s. When asked if 
Table 2. Details of the salmon harvests described by Inuvialuit fishers in the six communities in the ISR.

\begin{tabular}{|c|c|c|c|c|c|c|c|c|c|c|c|c|c|c|}
\hline & \multicolumn{3}{|c|}{ Location } & \multicolumn{2}{|c|}{ Method } & \multicolumn{2}{|c|}{ Colour } & \multicolumn{2}{|c|}{ Conditions } & \multicolumn{2}{|c|}{ Timing } & \multicolumn{3}{|l|}{ Use } \\
\hline & Lake & River & Ocean & Hook & Net & Red & Silver & Healthy & Sick & Open & Ice & Consumption & Distribution & ASP \\
\hline Aklavik (9) & 0 & 8 & 1 & 0 & 9 & 4 & 7 & 8 & 1 & 8 & 2 & 5 & 3 & 2 \\
\hline Inuvik (6) & 1 & 5 & 3 & 0 & 6 & 3 & 5 & 4 & 2 & 6 & 0 & 3 & 0 & 3 \\
\hline Sachs Harbour (5) & 2 & 1 & 5 & 0 & 5 & 3 & 3 & 5 & 1 & 5 & 0 & 5 & 2 & 2 \\
\hline Ulukhaktok (9) & 9 & 1 & 5 & 1 & 9 & 2 & 7 & 8 & 0 & 7 & 7 & 6 & 0 & 3 \\
\hline Paulatuk (6) & 1 & 4 & 2 & 1 & 6 & 2 & 4 & 5 & 2 & 4 & 2 & 1 & 0 & 5 \\
\hline
\end{tabular}

Note: Name of the community with the number of participants who caught salmon is shown in parentheses. Individual interview participants were counted more than once if they caught salmon across multiple categories. ASP represents instances where fishers returned their salmon to the Arctic Salmon Project.

there were ever salmon before the 1990s, Joe Kudlak said "I don't think so. Just the ones in a can!" In Ulukhaktok, the earliest primary record of salmon harvest occurred in the 1990s and was reported by a participant who was out fishing with his father, who had also never seen a salmon before. Since then, the number of people catching salmon, and the magnitude of the annual harvest have increased steadily (Fig. 3E). In response to this change Isaac Inuktalik noted "you can't stop the salmon from invading our island". In Paulatuk, the earliest account of salmon harvest occurred in the early 2000s. Prior to this, none of the fishers we interviewed had primary or secondary knowledge of salmon harvest. When we asked Noel Green about the changes in salmon harvest he told us that salmon are "hanging around, or making their way up here slowly". As with all of the other communities, the number of people catching salmon in Paulatuk and the number of salmon being harvested have increased since the 2000s (Fig. 3F).

\section{The nature of the salmon harvest}

Interview participants were clear that salmon harvest across the ISR is incidental and occurs during the harvest of primary subsistence fish including: Arctic char, Dolly Varden, whitefish, trout, and ciscoes (Coregonus spp.). With the exception of two participants in Aklavik, we did not speak to anyone who intentionally targeted salmon. Fishers are catching salmon wherever they fish, but harvesters who fished with a gill-net during the period from AugustOctober generally caught the most salmon.

Across the entire ISR, reports of salmon harvest occurred most frequently in nearshore marine waters, followed by rivers, then lakes (Table 2). Variation from this pattern in individual communities was due to the fact that salmon were most often harvested in the most popular fishing locations of each community. Communities where fishing occurs in closed lakes reported fewer salmon harvests than communities who fish mostly in the ocean, rivers, or lakes connected to the ocean (Table 2). Participants in all six communities also reported that incidental salmon harvest is expanding geographically within their region, as people are regularly catching salmon in new locations.

Participants reported catching the most salmon during the open water period, between July and October. After freeze-up, people continue to catch salmon, but less frequently, in fewer numbers, and exclusively in rivers and lakes. Some participants also noted that the dates of first and last catch every year were extending earlier and later, respectively. Elders in Aklavik who had been catching salmon their whole life remember catching salmon in the narrow window immediately before freeze-up, but not after. Interview participants made it clear that salmon harvest in the last two decades has begun well before freeze-up, as early as July, and extends far into the winter months, typically as late as December.

Across the ISR, interview participants reported catching salmon in their silver phase more frequently than in their spawning phase (Table 2). This was true in every community except for Sachs Harbour, where participants reported catching an even distribution of silver and spawning phases. When we asked about salmon health,
Table 3. Potential causes of changing Pacific salmon harvest levels as described by Inuvialuit fishers.

\begin{tabular}{ll}
\hline Cause & $\begin{array}{l}\text { No. of participants } \\
(n=53)\end{array}$ \\
\hline Climate change & 45 \\
Increased air temperature & 13 \\
Changing water levels (rivers) & 9 \\
Changing ice thickness, extent, and timing & 6 \\
Increased water temperature & 5 \\
Changing weather patterns & 5 \\
Permafrost thaw & 4 \\
Changing water quality & 3 \\
Increased development & 5 \\
A change in the earth's axis & 3
\end{tabular}

Note: Indented causes were discussed as subcategories of broad-scale climate change. The number of participants indicate how many people referred to each cause as a specific driver of changes.

most fishers indicated that fish generally seemed to be in good condition (Table 2), but frequently noted that they were not familiar with indicators of salmon health, like they were for culturally important food fish. As a fisher in Paulatuk noted, "I wouldn't know what healthy is for them".

\section{Causes of range expansions}

Our interviews revealed a range of factors that may be driving shifts in salmon catches, but the majority of fishers pointed to changing climatic conditions as the root cause (Table 3). A Paulatuk harvester said "I think it's global warming. That's the big issue today and we're not blind to it up here, we're seeing it first-hand". Table 3 summarizes the direct (e.g., increased water temperature) and indirect (e.g., permafrost thaw) effects of climate change that participants noted were influencing salmon ranges. Some participants also discussed additional, possibly compounding, factors influencing salmon harvests such as disturbances in salmon native ranges related to oil exploration in Alaska, earthquakes, or native stream destruction.

\section{Impacts of increased salmon}

All participants expressed concern about potential interactions between salmon and other fish species, but most of the fishers we spoke with told us that they did not know enough to describe the effects that salmon have on local fishes with certainty. Of the 53 people we interviewed, only five confidently described interactions between local fish species and salmon. All of these interactions were described as negative. Despite this uncertainty, or perhaps because of it, most Inuvialuit fishers consider salmon an unwelcome addition to their waters. "I think they scare our char", said Margaret Kanayok from Ulukhaktok. Many participants described the potential for negative competitive and predatory interactions between salmon and culturally 
Fig. 4. Photos of salmon in the ISR. (A) A chum salmon (right side) drying next to broad whitefish in Tuktoyaktuk (photo: Zander Chila); (B) a sockeye salmon harvested in the same net as Arctic char and broad whitefish from the Hornaday River in November (photo: Steve Illasiak); (C) a fisher preparing salmon for drying at Shingle Point (photo: Collin Gallagher); (D) salmon heads returned to the Arctic Salmon Project (photo: Colin Gallagher).
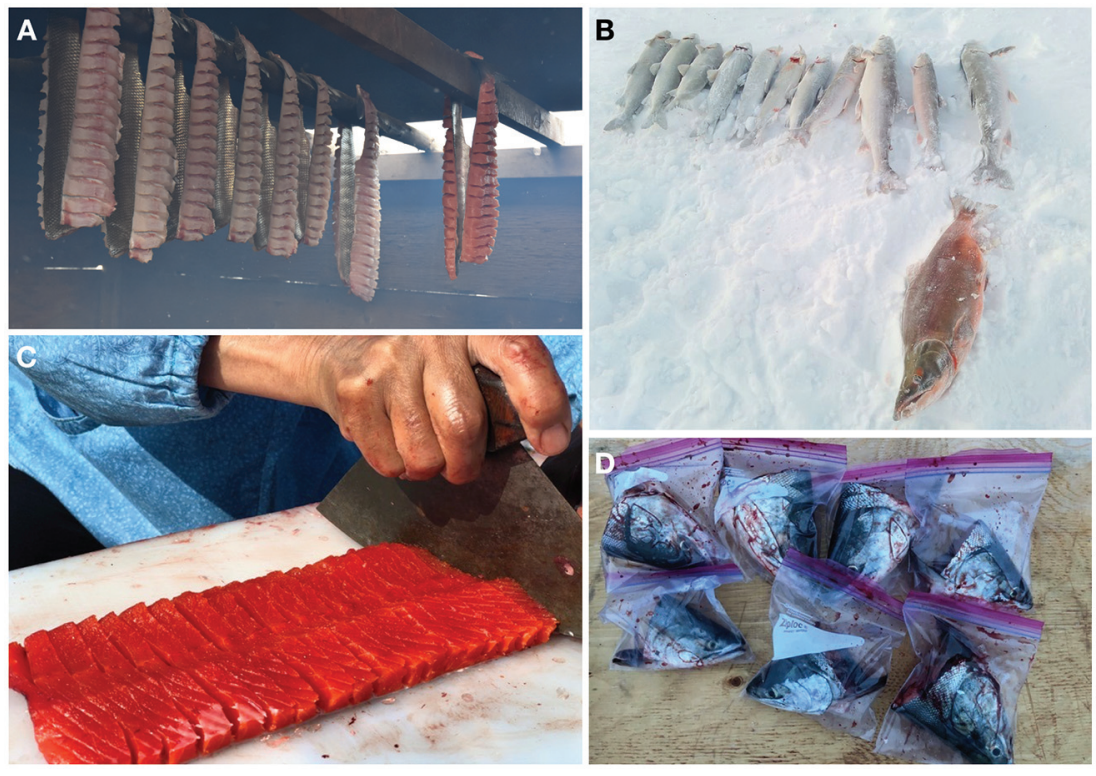

important food fish such as Arctic char and broad whitefish. Several specific effects on local fish were noted and cautiously attributed to salmon. All communities except Sachs Harbour reported catching more local fish (non-salmon) with scars or open wounds. These wounds were thought to be inflicted by mammals or other fish, particularly salmon given the correlation between increasing harvests of salmon and scarred fish. All communities reported catching more fish with parasites and more fish with soft flesh. Both of these health concerns were linked to warming waters, and some participants hypothesized that salmon may be transporting parasites into Arctic waters. Even fishers in Aklavik, who have a long history of harvesting salmon, expressed concerns about the negative impacts of increasing salmon populations on other fish. Underlying this view was a concern that even if salmon do not have direct negative impacts on local fish populations, salmon are responding to broad-scale changes (Table 3), which will have negative impacts on local fish populations.

\section{Sociocultural changes}

While not the focus of our interviews, many participants expressed concerns about the impact of salmon and climate change on the cultural practice of fishing. In Inuvik we spoke with Doug Esagok about the intergenerational knowledge of fishing practices, and he told us that what some fishers "learned growing up we can't even apply it today because it's so different. It's just like we don't live in the same place anymore". This concern was also linked with the importance of fish for health and well-being. In Tuktoyaktuk, a harvester told us "it's very concerning because most everybody in Tuk likes to fish. They depend on the whitefish". Concerns about how salmon would impact Inuvialuit fishing were widespread and showed no clear geographic or demographic patterns. Despite these concerns, many fishers noted their confidence that they could respond to changes in salmon. John Sam Green in Paulatuk noted that "You learn to adapt; you learn to find new ways". These conversations highlighted that local and traditional knowledges are not static, nor are Inuvialuit fishing practices.

While we did not have nuanced discussions about specific adaptations, people are now fishing in different areas, at different times, and with different techniques to practice Inuvialuit culture and to supply families and communities with appropriate food. While salmon are ubiquitously considered a threat, many people will still eat them (Fig. 4). Of the 43 participants who had personally caught salmon, 23 ate these fish, 19 returned them to the ASP, and seven distributed the salmon throughout the community for others to eat (Table 2). Paulatuk was unique in their use of salmon, as we only heard one account of someone eating the fish; everyone else returned their salmon to the ASP. As one participant explained, everyone is returning their salmon to the ASP "not because of the benefits monetarily but trying to understand why they [salmon] are coming into our area".

\section{Discussion}

Widespread reports of increasing salmon harvest in areas of the western Arctic where there is no precedent of these species provide additional evidence that regional changes in climate are driving the northward range expansion of Pacific salmon (Babaluk et al. 2000; Carothers et al. 2019; Dunmall et al. 2018; Farley et al. 2020; Nielsen et al. 2020; Yoon et al. 2015). In our interviews, $85 \%$ of participants cited the direct and indirect effects of climate change as the main drivers of the increase in Pacific salmon harvest. Increasing sea surface temperatures; decreasing sea ice duration, extent, and thickness; and increased marine productivity (Gibson et al. 2020; IPCC 2019; Niemi et al. 2019) may be contributing to increased salmon abundance by ameliorating the environmental conditions in the Arctic Ocean for salmon survival. Oceanographic changes could also be affecting salmon abundance through an altered seasonal cycle (Carton et al. 2015) and changing ocean currents (Niemi et al. 2019). Additionally, these oceanographic factors could be contributing to changes in salmon harvest such as fishers catching salmon later in the fall and winter. The observations from our interviews are also consistent with projections of a northward range shift based on bioenergetic and life history models for chum and pink salmon (Farley et al. 2020; Yoon et al. 2015).

Our interviews, combined with historical records of harvest and unpublished ASP data, indicate that the range margin of Pacific salmon now extends further north than widely recognized in the literature (Fig. 1) (Abdul-Aziz et al. 2011). Fishers in Aklavik have been catching salmon for generations; in 1979 the 
Table 4. Changes to local fish harvests described in the interviews.

\begin{tabular}{|c|c|c|c|}
\hline Community affected & Change & Potential causes cited in interviews & Consensus \\
\hline All & $\begin{array}{l}\text { Increased variability of fish harvest composition and } \\
\text { yield and a decreasing trend in harvest yield }\end{array}$ & $\begin{array}{l}\text { Changes in local fish populations and } \\
\text { increase in adverse weather conditions }\end{array}$ & High \\
\hline All & $\begin{array}{l}\text { Increase in the variability of population demographics } \\
\text { (e.g., size) and migration timing }\end{array}$ & Climate change & High \\
\hline All & Increase in the number of fish with parasites* & $\begin{array}{l}\text { Warming waters, and salmon may be } \\
\text { acting as vectors for parasites }\end{array}$ & Moderate \\
\hline All & Increase in fish with soft flesh & Warmer waters & High \\
\hline $\begin{array}{l}\text { Tuktoyaktuk and } \\
\text { Aklavik }\end{array}$ & Decrease in the harvest of local herring & Climate change & High \\
\hline Paulatuk & $\begin{array}{l}\text { Change in Arctic char flesh colour, from bright orange to } \\
\text { pale or white* }\end{array}$ & $\begin{array}{l}\text { Increase in salmon and (or) climate } \\
\text { change }\end{array}$ & High \\
\hline Sachs Harbour & Lasting declines in Arctic char harvest* & $\begin{array}{l}\text { Increase in salmon and decrease in Arctic } \\
\text { char population }\end{array}$ & High \\
\hline
\end{tabular}

community recorded a harvest of 11547 chum salmon (Stephenson 2006). There is at least one population of chum salmon natal to the Mackenzie River drainage (Coad et al. 2018; Dunmall 2018; Irvine et al. 2009), and it is likely that Aklavik's historical harvests of chum salmon originated from this population (Stephenson 2006). It is possible that semi-regular salmon harvests in the Outer communities began earlier than the reports from our interviews, but we consider this unlikely. Participants from these communities noted that their elders had never caught salmon, nor did they mention their elders regularly catching other novel fish. While fishers may not have known what salmon were if they caught them, they would certainly have known that they were unusual. Given the nature of our interviews and expertise of the participants, we can assume that a semi-regular harvest of unusual fish would have been reported. While the voluntary nature of the ASP data collection limits the interpretation of that data, our interviews unambiguously indicate that more people are catching salmon now that in previous decades. Further, fishers often told us that the number of salmon being reported was a consistent underestimation of the salmon being harvested in each community. This information supports interpreting the increase in salmon returned to the ASP as an increase in harvested salmon. Note that we distinguish between salmon harvest and salmon abundance, as the number of salmon that people harvest does not necessarily reflect the abundance of salmon in the ISR, and the relationship between salmon harvest and abundance is beyond the scope of this research.

According to Aklavik fishers and the published literature, the salmon harvest has always been subject to high interannual variation (Stephenson 2006). This variation is also evident in the salmon harvests that have emerged in Sachs Harbour, Ulukhaktok, and Paulatuk in recent decades (Dunmall et al. 2018). Fishers mentioned that the interannual and regional variation in salmon harvests has many drivers. Interannual variation is driven by both fishing conditions and salmon abundance. In other words, a large annual salmon harvest can only occur if the fishing conditions are suitable and the salmon are present. Regional differences in salmon harvest are influenced by salmon abundance, but may also be driven by diverging local fishing practices. This suggests that historical harvest and knowledge of salmon is related to historical fishing conditions, salmon abundance, and local fishing practices. A complete investigation into how these factors have influenced local knowledges of salmon throughout the ISR is beyond the scope of our study, but could be an interesting avenue for future research, as it would better contextualize our understanding of historical salmon occurrences in the Arctic.

While early increases in salmon harvest in the ISR mirror increases throughout the North Pacific, more recent changes indicate that these systems may be diverging. The increasing harvest of salmon across the ISR in the mid-1990s corresponds to a period of high abundance of salmon in the North Pacific and an above average salmon harvest in Iñupiat communities on the North Slope of Alaska (Carothers et al. 2019; Ruggerone and Irvine 2018). Within the last decade, however, the abundance of salmon in the North Pacific has declined (Mueter et al. 2002; Ruggerone and Irvine 2018; Welch et al.1998), but catches on Alaska's North Slope and in Arctic Canada have remained high or increased (Carothers et al. 2019). Iñupiat communities on the Alaska North Slope (Carothers et al. 2019), communities along the Mackenzie River (Dunmall et al. 2018), and Inuit communities throughout Nunavut (Bilous and Dunmall 2020; ASP, unpublished data) are experiencing increasing salmon harvests and are concerned about the impacts of these changes. Research on barriers and opportunities for salmon colonizing the Arctic has not been extensive (Dunmall et al. 2016; Nielsen et al. 2020; Salonius 1973; Yoon et al. 2015), but the consensus is that salmon abundance in the Arctic will likely increase (Connors et al. 2020; Farley et al. 2020; Yoon et al. 2015).

Concerns about the impact of salmon, and a lack of data on interactions among species, highlight the urgent need for more research. At present the ecological relationships between Pacific salmon and each of Arctic char, Dolly Varden, and broad whitefish remain understudied. Interview participants made it clear that these species are occupying the same physical spaces, but little is known about the diet of salmon in the Arctic or its overlap with the diet of Arctic fishes. Salmon diet likely varies with differences in functional morphology, physiology, and environment (Auburn and Ignell 2000; Kaeriyama et al. 2004; Tadokoro et al. 1996; Qin and Kaeriyama 2016); therefore, data from other regions cannot be used to infer competitive potential. The plasticity of Arctic char diets has facilitated their coexistence with some competitive species (Eloranta et al. 2011; Morrissey-McCaffrey et al. 2019), but studies in other regions suggest that new competitive interactions mediated by climate change will reduce habitat for Arctic char (Hein et al. 2012). The change in colour of Arctic char flesh described in Paulatuk and lasting declines of Arctic char in Sachs Harbour may indicate that changes to the physiology and abundance of local fish population have already begun (Table 4). 
Comparable research on the responses of Dolly Varden and broad whitefish to climate change is more limited and highlights the need for further study. In some regions, salmon-derived nutrients have been shown to increase the fitness of stream-resident fishes (Bilby et al. 1996; Denton et al. 2009; Jaecks and Quinn 2014; Wipfli et al. 2003), providing up to $80 \%$ of the nutrients for some populations of Dolly Varden (Jaecks and Quinn 2014). Both Dolly Varden and Arctic char have been shown to benefit from salmon-derived nutrients, but it is unclear if broad whitefish may also benefit in this way. Additionally, the benefits of salmon to other fishes are mediated by genetics and environment (Denton et al. 2010), and it is unclear if these interactions would be similar in the ISR. Stable isotope analyses investigating the use of salmon nutrient subsidies and potential dietary competition between salmon and Arctic fishes will be critical to advance our understanding of climate change impacts on species assemblages in the ISR (Bilby et al.1996; Denton et al. 2009; Jaecks and Quinn 2014; Wipfli et al. 2003). Given the importance of local fisheries, this research will be critical for developing a management strategy for salmon in the Arctic that accounts for the potential impacts of salmon on Inuvialuit fishing practices and culture.

Inuvialuit fishers do not welcome increasing salmon harvests because of their potentially negative impacts on culturally important fisheries. John Keogak from Sachs Harbour illustrates the connection between fishing and Inuvialuit culture by saying there's "nothing better to do than fish". Fishing supports a range of sociocultural activities in the ISR, and as such its "intangible cultural relevance is incalculable" (ICC 2020, p. 22). In five of the six communities, we spoke with fishers who really enjoy eating salmon, but could not separate their enjoyment from their concerns about potential social-ecological impacts. Speaking to this, a participant in Sachs Harbour noted that "it was really something to catch a salmon, really everybody's happy to get a couple of salmon. . .but now get this damn thing out of here!" By affecting Arctic fish populations, salmon have the potential to interfere with important cultural relationships.

Many fishers were not sure about the nature of salmon's ecological or sociocultural effects, but it is clear from our interviews that salmon are an indicator of climate and environmental changes (Tables 3 and 4). Every participant with whom we spoke highlighted the threat these changes pose to Inuvialuit society and culture. We did not investigate this deeply in our interviews, but the potential sociocultural impacts of climate change are thoroughly described in the literature. These impacts span physical health and nutrition (Wesche and Chan 2011), emotional well-being (Cunsolo Willox et al. 2015; ICC 2020; Searles 2002), relationships within and between communities (Moerlein and Carothers 2012; Searles 2002), and relationships with the land itself (Cunsolo Willox et al. 2015; ICC 2020; Moerlein and Carothers 2012). They also influence local economies (LeDuc 2006) and politics (Martello 2008). There is currently no management strategy for salmon in the ISR. Given their wide-reaching impacts, research to develop a salmon strategy must consider their sociocultural impacts. In this study, we have presented the necessary foundation for that sociocultural research.

Despite the impacts of climate change and salmon on Arctic fish, many harvesters we spoke with expressed optimism about the future of Inuvialuit fisheries. The ways that salmon will affect the sociocultural practice of fishing remain unclear, but participants stressed their ability to adapt. Joseph Carpenter in Sachs Harbour said, "We can't really do anything here about it, so the trick is to adapt to it. And people are doing that". Harvesters told us that they will continue to eat the salmon so long as it is healthy, but often noted that they did not know how best to prepare salmon and were curious to learn new ways. In response, the ASP created an Arctic salmon cookbook (Fisheries and Oceans Canada 2020) with the hopes that this might contribute to adaptive efforts.

In this study, we combined interviews and harvest data from the Arctic Salmon Program to expand our knowledge of salmon in Arctic regions. This practice is common in the field of ethnoecology, but its application is still emerging in fisheries contexts (Cooke et al. 2021). Other recent studies point to local and (or) Indigenous knowledge being used to develop and validate species distribution models (Lima et al. 2017; Lopes et al. 2018) and to perform broad ecosystem assessments (Rosellon-Druker et al. 2019). The methods we present here could be adapted for research on other species or regions and contribute to a better understanding of ecological systems and their social dimensions. Given the uncertainty regarding the effects of climate change and salmon, efforts to understand the social dimensions of change and support adaptive fishing practices are crucial. Given the potential impacts to Inuvialuit livelihoods, these efforts must be informed by, and center on, Inuvialuit perspectives and values.

\section{Competing interests statement}

The authors declare that there are no competing interests.

\section{Funding statement}

Funding for this research was provided by Fisheries and Oceans Canada, the Tracking Change project (SSHRC 895-2015-102), the Fisheries Joint Management Committee, the University of Victoria, a SSHRC Canada Graduate Scholarship, and a Weston Family Award for Northern Research.

\section{Contributors' statement}

The FJMC conceived the research project. Z.C., K.D., and T.L. created the project plan, which was then approved by the FJMC, Inuvialuit Game Council, and each HTC. Z.C., K.D., T.L., and the HTCs developed interview strategies and guides. The HTCs selected interview participants and hired a local interviewer. Z.C., T.P., and the local interviewers conducted the interviews. Z.C. analyzed the interview transcripts and drafted the results. HTCs validated the results, provided additional context and nuance to our interpretation, and indicated which findings were appropriate and important to include in this manuscript. Z.C. prepared the manuscript with input from K.D., T.P., and T.L. FJMC and HTCs reviewed the manuscript. K.D. and T.L. provided funding and supervised the project. Fishers and elders in each community contributed their knowledge, feedback, and direction at open-house community presentations and dinners. HTCs chose whether or not to be listed as co-authors.

\section{Data availability statement}

Due to the confidential nature of the data presented here, data are unavailable to the public. Interview recordings and transcripts are available to Inuvialuit through the Joint Secretariat Inuvialuit Traditional and Local Knowledge coordinator.

\section{Acknowledgements}

The authors humbly thank all of the interview participants who shared their knowledge: Agnes Kuptana, Allen Kogiak, Bertha Joe, Brian Wade, Cheryl Arey, Christopher Felix, Dean Arey, Doug Esagok, Eileen Jacobson, George Krengektak, Hank Angasuk, Isaac Inuktalik, Jack Akhiatak, Jeff Kuptana, Jerry Angasuk, Jody Illasiak, Joe Kudlak, John Keogak, John Sam Green, Johnnie Storr, Joseph Carpenter, Kate Inuktalik, Lawrence Kaglik, Lawrence Ruben, Lena Wolki, Liz Kuptana, Mabel Noksana, Margaret Kanayok, Melissa D. Rogers, Michael Green, Michelle Gruben, Miles Robert Dillon, Sr., Nellie Arey, Noel Green, Patrick Akhiatak, Phillip Ross, Randy Gruben, Rebecca Kaglik, Renie Arey, Richard Carpenter, Robert Kuptana, Roland Notaina, Steve Illasiak, Tony Alanak, Tony Green, Trevor Lucas, Wayne Thrasher, William Storr, and those who chose to remain anonymous. We acknowledge the significant contributions from the Tuktoyaktuk Hunters and Trappers Committee, who chose not to be co-authors. 
Quyanainni to the communities of Aklavik, Inuvik, Paulatuk, Sachs Harbour, Tuktoyaktuk, and Ulukhaktok for your warm welcomes in the cold weather and for providing the foundations of this work. Thank you to all of the employees for each Hunters and Trappers Committee, the Inuvialuit Game Council, and the Fisheries Joint Management Committee for your support and guidance. We thank Tait Overeem for helping with the interview transcription, and Mike Newton for creating the map. Thank you, Colin Gallagher and Steve Illasiak for the use of your photos. Finally, thank you to past and present members of the Environmental Studies program at UVic and colleagues at DFO - specifically Darcy McNicholl, Kevin Gully, Kiyo Campbell (FJMC), Hana Travers-Smith, Tanya Tran, Angel Chen, Jordan Seider, and Nicola Shipman.

\section{References}

Abdul-Aziz, O., Mantua, N., and Myers, K. 2011. Potential climate change impacts on thermal habitats of Pacific salmon (Oncorhynchus spp.) in the North Pacific Ocean and adjacent seas. Can. J. Fish. Aquat. Sci. 68(9): 1660-1680. doi:10.1139/f2011-079.

AHTC (Aklavik Hunters and Trappers Committee), Aklavik Community Corporation, The Wildlife Management Advisory Council (NWT), The Fisheries Joint Management Committee, and the Joint Secretariat. 2016. Aklavik Community Conservation Plan Akaqvikmiut Angalatchivingit Niryutinik. Aklavik, NWT. Available from https://static1.squarespace.com/ static/5e2093a7fd6f455447254aff/t/5e2f2af9871a582cf4b55785/1580149532235/ 2016-Aklavik-Community-Conservation-Plan-R.pdf.

Alunik, I., Morrison, D.A., and Kolausok, E.D. 2003. Across time and tundra: the Inuvialuit of the western Arctic. Raincoast Books, Vancouver, B.C.

Auburn, M.E., and Ignell, S.E. 2000. Food habits of juvenile salmon in the Gulf of Alaska July-August 1996. N. Pac. Anadr. Fish Comm. Bull. No. 2. North Pacific Anadromous Fish Commission, Vancouver, B.C. pp. 89-97.

Augerot, X., and Foley, D., 2005. Atlas of Pacific salmon. University of California Press, Oakland, Calif. Available from https://www.ucpress.edu/ book/9780520245044/atlas-of-pacific-salmon [Accessed 15 March 2021].

Babaluk, J.A., Reist, J.D., Johnson, J.D., and Johnson, L. 2000. First records of sockeye (Oncorhynchus nerka) and pink salmon (0. gorbuscha) from Banks Island and other records of Pacific salmon in Northwest Territories, Canada. Arctic, 53(2): 161-164. doi:10.14430/arctic846.

Bilby, R., Fransen, B., and Bisson, P. 1996. Incorporation of nitrogen and carbon from spawning coho salmon into the trophic system of small streams: evidence from stable isotopes. Can. J. Fish. Aquat. Sci. 53(1): 164-173. doi:10.1139/f95-159.

Bilous, M., and Dunmall, K. 2020. Atlantic salmon in the Canadian Arctic: potential dispersal, establishment, and interaction with Arctic char. Rev. Fish Biol. Fish. 30(3): 463-483. doi:10.1007/s11160-020-09610-2.

Binder, L., and Hanbidge, B. 1993. The Inuvialuit of the western Arctic and resource: co-management under a land claims settlement. In Traditional Ecological Knowledge: Concepts and Cases. Edited by J. Inglis. Canadian Museum of Nature, Ottawa, Ont. pp. 121-132.

Bintanja, R., and Andry, O. 2017. Towards a rain-dominated Arctic. Nat. Clim. Change, 7(4): 263-267. doi:10.1038/nclimate3240.

Cameron, E.S. 2012. Securing Indigenous politics: a critique of the vulnerability and adaptation approach to the human dimensions of climate change in the Canadian Arctic. Global Environ. Change, 22(1): 103-114. doi:10.1016/j.gloenvcha.2011.11.004

Carothers, C., Sformo, T.L., Cotton, S., George, J.C., and Westley, P.A.H. 2019. Pacific salmon in the rapidly changing Arctic: exploring local knowledge and emerging fisheries in Utqiagivik and Nuiqsut, Alaska. Arctic, 72(3): 273-288. doi:10.14430/arctic68876.

Carton, J.A., Ding, Y., and Arrigo, K.R. 2015. The seasonal cycle of the Arctic Ocean under climate change. Geophys. Res. Lett. 42(18): 7681-7686. doi:10.1002/ 2015GL064514.

Castleden, H., Morgan, V.S., and Lamb, C. 2012. I spent the first year drinking tea: exploring Canadian university researchers' perspectives on community-based participatory research involving Indigenous peoples. Can. Geogr. 56(2): 160-179. doi:10.1111/j.1541-0064.2012.00432.x.

Chen, A., Lantz, T.C., Hermosilla, T., and Wulder, M.A. 2021. Biophysical controls of increased tundra productivity in the western Canadian Arctic. Remote Sens. Environ. 258: 112358. doi:10.1016/j.rse.2021.112358.

Coad, B.W., Reist, J.D., Moller, P.R., Renaud, C.B., Alfonso, N.R., Dunmall, K., et al. 2018. Marine Fishes of Arctic Canada. University of Toronto Press. Available from https://www.jstor.org/stable/10.3138/j.ctt1x76h0b.

Connors, B., Malick, M.J., Ruggerone, G.T., Rand, P., Adkison, M., Irvine, J.R., et al. 2020. Climate and competition influence sockeye salmon population dynamics across the Northeast Pacific Ocean. Can. J. Fish. Aquat. Sci. 77(6): 943-949. doi:10.1139/cjfas-2019-0422.

Cooke, S.J., Nguyen, V.M., Chapman, J.M., Reid, A.J., Landsman, S.J., Young, N., Hinch, S.G., Schott, S., Mandrak, N.E., and Semeniuk, C.A.D. 2021. Knowledge co-production: A pathway to effective fisheries management, conservation, and governance. Fisheries, 46(2): 89-97. doi:10.1002/fsh.10512.

Cunsolo Willox, A., Stephenson, E., Allen, J., Bourque, F., Drossos, A., Elgarøy, S., et al. 2015. Examining relationships between climate change and mental health in the Circumpolar North. Reg. Environ. Change, 15(1): 169-182. doi:10.1007/s10113-014-0630-z.

Denton, K.P., Harry, B.R., Jr., and Quinn, T.P. 2009. Diet, movement, and growth of Dolly Varden in response to sockeye salmon subsidies. Trans. Am. Fish. Soc. 138(6): 1207-1219. doi:10.1577/T09-006.1.

Denton, K.P., Rich, H.B., Moore, J.W., and Quinn, T.P. 2010. The utilization of a Pacific salmon (Oncorhynchus nerka) subsidy by three populations of charr Salvelinus spp. J. Fish Biol. 77(4): 1006-1023. doi:10.1111/j.1095-8649.2010.02746.x.

Drew, J.A. 2005. Use of traditional ecological knowledge in marine conservation. Conserv. Biol. 19(4): 1286-1293. doi:10.1111/j.1523-1739.2005.00158.x.

Dunmall, K. 2018. Pacific salmon in the Canadian Arctic: indicators of change. Ph.D., University of Manitoba, Winnipeg, Man. Available from https://mspace.lib.umanitoba.ca/bitstream/handle/1993/32856/Dunmall_ Karen.pdf?sequence=3\&isAllowed=y.

Dunmall, K.M., McNicholl, D.G., and Reist, J.D. 2018. Community-based monitoring demonstrates increasing occurrences and abundances of Pacific salmon in the Canadian Arctic from 2000 to 2017. North Pacific Anadromous Fish Commission Tech. Rep. 11: 87-90. doi:10.23849/npafctr11/87.90.

Dunmall, K.M., Mochnacz, N.J., Zimmerman, C.E., Lean, C., and Reist, J.D. 2016. Using thermal limits to assess establishment of fish dispersing to high-latitude and high-elevation watersheds. Can. J. Fish. Aquat. Sci. 73(12): 1750-1758. doi:10.1139/cjfas-2016-0051.

Dunmall, K.M., Reist, J.D., Carmack, E.C., Babaluk, J.A., Heide-Jorgensen, M.P., and Docker, M.F. 2013. Pacific salmon in the Arctic: harbingers of change. In Responses of Arctic Marine Ecosystems to Climate Change. Edited by F.J. Mueter, D.M.S. Dickson, H.P. Huntington, and J.R. Irvine. University of Alaska Fairbanks, Alaska Sea Grant. doi:10.4027/ramecc.2013.07.

ECG. 2009. Ecological regions of the Northwest Territories, Taiga Plains. Ecosystem Classification Group, Department of Environment and Natural Resources, Government of the Northwest Territories, Yellowknife, NWT.

ECG. 2012. Ecological regions of the Northwest Territories, Southern Arctic. Ecosystem Classification Group, Department of Environment and Natural Resources, Government of the Northwest Territories, Yellowknife, NWT.

ECG. 2013. Ecological regions of the Northwest Territories, Northern Arctic. Ecosystem Classification Group, Department of Environment and Natural Resources, Government of the Northwest Territories, Yellowknife, NWT.

Eloranta, A.P., Siwertsson, A., Knudsen, R., and Amundsen, P.-A. 2011. Dietary plasticity of Arctic charr (Salvelinus alpinus) facilitates coexistence with competitively superior European whitefish (Coregonus lavaretus). Ecol. Freshw. Fish. 20(4): 558-568. doi:10.1111/j.1600-0633.2011.00504.x.

Farley, E.V., Murphy, J.M., Cieciel, K., Yasumiishi, E.M., Dunmall, K., Sformo, T., and Rand, P. 2020. Response of Pink salmon to climate warming in the northern Bering Sea. Deep Sea Res. Part II Top. Stud. Oceanogr. 177: 104830. doi:10.1016/j.dsr2.2020.104830.

Fisheries and Oceans Canada. 2020. A salmon cookbook for the Arctic. 1st ed. Edited by L. Christie, K. Dunmall, M. Bilous, D. McNicholl, and J. Reist. Available from https://www.researchgate.net/publication/340309134_A_ Salmon Cookbook for the Arctic.

Ford, J.D., Willox, A.C., Chatwood, S., Furgal, C., Harper, S., Mauro, I., and Pearce, T. 2014. Adapting to the effects of climate change on Inuit health. Am. J. Public Health, 104(Suppl. 3): e9-e17. doi:10.2105/AJPH.2013.301724. PMID:24754615.

Gibson, G., Weijer, W., Jeffery, N., and Wang, S. 2020. Relative impact of sea ice and temperature changes on Arctic marine production. J. Geophys. Res. Biogeosci. 125(7): e2019JG005343. doi:10.1029/2019JG005343.

Government of Canada. 1984. The Western Arctic Claim: the Inuvialuit Final Agreement. Department of Indian and Northern Development, Ottawa, Ont.

Grenier, L. 1998. Working with Indigenous knowledge: a guide for researchers. IDRC.

Groot, G. 1991. Pacific salmon life histories. University of British Columbia Press, Vancouver, B.C.

Groot, C. 2010. Physiological ecology of Pacific salmon. University of British Columbia Press, Vancouver, B.C.

Hein, C.L., Öhlund, G., and Englund, G. 2012. Future distribution of Arctic char (Salvelinus alpinus) in Sweden under climate change: effects of temperature, lake size and species interactions. Ambio, 41(3): 303-312. doi:10.1007/s13280012-0308-z. PMID:22864703.

Houde, N. 2007. The Six Faces of Traditional Ecological Knowledge: Challenges and Opportunities for Canadian Co-Management Arrangements. Ecol. Soc. 12(2): 34. doi:10.5751/ES-02270-120234.

ICC. 2020. Food Sovereignty and Self-Governance: Inuit role in managing Arctic marine resources. Inuit Circumpolar Council Alaska (ICC), Anchorage, Alaska. Available from https://iccalaska.org/wp-icc/wp-content/uploads/2020/09/FSSGReport_-LR.pdf.

IHTC (Inuvik Hunters and Trappers Committee), Inuvik Community Corporation, The Wildlife Management Advisory Council (NWT), The Fisheries Joint Management Committee, and the Joint Secretariat. 2016. Inuvik Community Conservation Plan: Inuuvium Angalatchivingit Niryutinik. Inuvik. Available from https://static1.squarespace.com/static/5e2093a7fd6f455447254aff/t/ 5e262b04166a41157ca93855/1579559719275/2016-Inuvik-Community-ConservationPlan-R.pdf. 
Inglis, J. 1993. Traditional ecological knowledge: concepts and cases. IDRC.

IPCC. 2019. IPCC special report on the ocean and cryosphere in a changing climate. Intergovernmental Panel on Climate Change (IPCC), Geneva, Switzerland.

IRC. 2018. Inuvialuit on the front line of climate change. Inuvialuit Regional Corporation (IRC), Inuvik, NWT.

Irvine, J., Linn, E., Gillespie, K., Mcleod, C., and Reist, J. 2009. Pacific salmon in Canada's Arctic draining rivers with emphasis on those in British Columbia and the Yukon. Pacific Fisheries Resource Conservation Council

Jaecks, T., and Quinn, T.P. 2014. Ontogenetic shift to dependence on salmonderived nutrients in Dolly Varden char from the Iliamna River, Alaska. Environ. Biol. Fish. 97(12): 1323-1333. doi:10.1007/s10641-014-0221-3.

Johannes, R.E. 1989. Traditional ecological knowledge: a collection of essays. IUCN, Gland. Available from https://www.iucn.org/content/traditional-ecologicalknowledge-a-collection-essays [Accessed 5 February 2021].

Kaeriyama, M., Nakamura, M., Edpalina, R., Bower, J., Yamaguchi, H., Walker, R., and Myers, K. 2004. Change in feeding ecology and trophic dynamics of Pacific salmon (Oncorhynchus spp.) in the central Gulf of Alaska in relation to climate events. Fisheries Oceanogr. 13: 197-207. doi:10.1111/j.13652419.2004.00286.x.

Krupnik, I., Aporta, C., Gearheard, S., Laidler, G.J., and Holm, L.K. (Editors). 2010. SIKU: knowing our ice - documenting Inuit sea ice knowledge and use. Springer Netherlands. doi:10.1007/978-90-481-8587-0.

Kuhnlein, H.V., and Receveur, O. 1996. Dietary change and traditional food systems of Indigenous peoples. Annu. Rev. Nutr. 16: 417-442. doi:10.1146/ annurev.nu.16.070196.002221.

Lantz, T.C., and Kokelj, S.V. 2008. Increasing rates of retrogressive thaw slump activity in the Mackenzie Delta region, N.W.T., Canada. Geophys. Res. Lett. 35(6). doi:10.1029/2007GL032433.

Leduc, T.B. 2006. Inuit economic adaptations for a changing global climate. Ecol. Econ. 60(1): 27-35. doi:10.1016/j.ecolecon.2006.02.004

Lima, M., Lins Oliveira, J., Nobrega, M., and Lopes, P. 2017. The use of Local Ecological Knowledge as a complementary approach to understand the temporal and spatial patterns of fishery resources distribution. J. Ethnobiol. Ethnomed. 13: 30. doi:10.1186/s13002-017-0156-9. PMID:28571574.

Linden, E. 1991. Lost tribes, lost knowledge. Time. pp. 46-54.

Lopes, P., Verba, J., Begossi, A., and Pennino, M. 2018. Predicting species distribution from fishers' local ecological knowledge: an alternative for data-poor management. Can. J. Fish. Aquat. Sci. 76(8): 1423-1431. doi:10.1139 cjfas-2018-0148.

Martello, M.L. 2008. Arctic Indigenous peoples as representations and representatives of climate change. Soc. Stud. Sci. 38(3): 351-376. doi:10.1177| 0306312707083665 . PMID:19069077.

Moerlein, K.J., and Carothers, C. 2012. Total environment of change: impacts of climate change and social transitions on subsistence fisheries in Northwest Alaska. Ecol. Soc. 17(1): 10. doi:10.5751/ES-04543-170110.

Montgomery, D. 2000. Coevolution of the Pacific salmon and Pacific Rim topology. Geology, 28: 1107-1110. doi:10.1130/0091-7613(2000)28<1107:COTPSA > 2.0.CO;2.

Morrissey-McCaffrey, E., Shephard, S., Kelly, F.L., and Kelly-Quinn, M. 2019. Non-native species and lake warming negatively affect Arctic char Salvelinus alpinus abundance; deep thermal refugia facilitate co-existence. J. Fish Biol. 94(1): 5-16. doi:10.1111/jfb.13837. PMID:30315584.

Mueter, F., Peterman, R., and Pyper, B. 2002. Opposite effects of ocean temperature on survival rates of 120 stocks of pacific salmon (Oncorhynchus spp.) in Northern and Southern Areas. Can. J. Fish. Aquat. Sci. 59(3): 456463. doi:10.1139/f02-020.

Nielsen, J., Rosing-Asvid, A., Meire, L., and Nygaard, R. 2020. Widespread occurrence of pink salmon (Oncorhynchus gorbuscha) throughout Greenland coastal waters. J. Fish Biol. 96(6): 1505-1507. doi:10.1111/jfb.14318.

Nielsen, J.L., Ruggerone, G.T., and Zimmerman, C.E. 2013. Adaptive strategies and life history characteristics in a warming climate: Salmon in the Arctic? Environ. Biol. Fish, 96(10): 1187-1226. doi:10.1007/s10641-012-0082-6.

Niemi, A., Ferguson, S., Hedges, K.H., MellingMichel, C., Ayles, B., et al. 2019. State of Canada's Arctic Seas. Canadian Technical Report of Fisheries and Aquatic Sciences. Available from http://publications.gc.ca/collections/ collection_2019/mpo-dfo/Fs97-6-3344-eng.pdf [Accessed 20 May 2020].

NOAA. 2017. Arctic Report Card 2017. National Oceanic and Atmospheric Administration (NOAA), Washington, D.C. Available from http://www. arctic.noaa.gov/Report-Card.

OHTC (Olokhaktomiut Hunters and Trappers Committee), Ulukhaktok Community Corporation, The Wildlife Management Advisory Council (NWT), The Fisheries Joint Management Committee, and the Joint Secretariat. 2016. Olokhaktomiut Community Conservation Plan: Ulukhaqtuum Angalatchivingit Niryutinik. Paulatuk, NWT. Available from https://static1.squarespace. com/static/5e2093a7fd6f455447254aff/t/5e262b83e3c0a94c0a904bf2/ 1579559867490/2016-Uluhaktok-Community-Conservation-Plan-R.pdf.

Pearce, T., Ford, J., Willox, A.C., and Smit, B. 2015. Inuit Traditional Ecological Knowledge (TEK), subsistence hunting and adaptation to climate change in the Canadian Arctic. Arctic, 68(2): 233-245. doi:10.14430/arctic4475.

PHTC (Paulatuk Hunters and Trappers Committee), Paulatuk Community Corporation, The Wildlife Management Advisory Council (NWT), The Fisheries Joint Management Committee, and the Joint Secretariat. 2016. Paulatuk Community Conservation Plan: Paulatuum Angalatchivingit Niryutinik. Paulatuk, NWT. Available from https://static1.squarespace.com/ static/5e2093a7fd6f455447254aff/t/5e274528c179bf7b311b59be/1579632 184779/2016-Paulatuk-Community-Conservation-Plan-R.pdf.

Proverbs, T.A., Lantz, T.C., Lord, S.I., Amos, A., and Ban, N.C. 2020. Socialecological determinants of access to fish and well-being in four Gwich'in communities in Canada's northwest territories. Hum. Ecol. 48: 155-171. doi:10.1007/s10745-020-00131-x.

Qin, Y., and Kaeriyama, M. 2016. Feeding habits and trophic levels of Pacific salmon (Oncorhynchus spp.) in the North Pacific Ocean. North Pacific Anadromous Fish Comm. Bull. 6: 469-481. doi:10.23849/npafcb6/469.481.

Reid, A.J., Eckert, L.E., Lane, J.-F., Young, N., Hinch, S.G., Darimont, C.T., et al. 2021. Two-Eyed Seeing: an Indigenous framework to transform fisheries research and management. Fish Fish. 22(2): 243-261. doi:10.1111/faf.12516.

Rosellon-Druker, J., Szymkowiak, M., Cunningham, C., Kasperski, S., Kruse, G., Moss, J., and Yasumiishi, E. 2019. Development of social-ecological conceptual models as the basis for an integrated ecosystem assessment framework in Southeast Alaska. Ecol. Soc. 24: 30. doi:10.5751/ES-11074-240330.

Ruggerone, G.T., and Irvine, J.R. 2018. Numbers and biomass of natural- and hatchery-origin pink salmon, chum salmon, and sockeye salmon in the North Pacific Ocean, 1925-2015. Mar. Coast. Fish. 10(2): 152-168. doi:10.1002/ mcf2.10023.

Salonius, P.O. 1973. Barriers to range extension of Atlantic and Pacific salmon in Arctic North America. Arctic, 26(2): 89-176. doi:10.14430/arctic2905.

Searles, E. 2002. Food and the making of modern Inuit identities. Food and Foodways, 10(1-2): 55-78. doi:10.1080/07409710212485.

SHHTC (Sachs Harbour Hunters and Trappers Committee), Sachs Harbour Community Corporation, The Wildlife Management Advisory Council (NWT), The Fisheries Joint Management Committee, and the Joint Secretariat. 2016. Sachs Harbour Community Conservation Plan: Sachs Harbour Angalatchivingit Niryutinik. Sachs Harbour, NWT. Available from https://static1.squarespace. com/static/5e2093a7fd6f455447254aff/t/5e2f2b5058c98526e5a69f9c/15801 49613890/2016-Sachs-Harbour-Community-Conservation-Plan-R.pdf.

Smith, H.A., and Sharp, K. 2012. Indigenous climate knowledges. WIREs Clim. Change, 3(5): 467-476. doi:10.1002/wcc.185.

Smith, L.T. 1999. Decolonizing methodologies: research and Indigenous peoples. Zed Books.

Stephenson, S.A. 2006. A review of the occurrence of Pacific salmon (Oncorhynchus spp.) in the Canadian Western Arctic. Arctic, 59(1): 37-46.

Tadokoro, K., Ishida, Y., Davis, N.D., Ueyanagi, S., and Sugimoto, T. 1996. Change in chum salmon (Oncorhynchus keta) stomach contents associated with fluctuation of pink salmon (0. gorbuscha) abundance in the central subarctic Pacific and Bering Sea. Fish. Oceanogr. 5(2): 89-99. doi:10.1111/ j.1365-2419.1996.tb00108.x.

Tape, K., Jones, B., Arp, C., Nitze, I., and Grosse, G. 2018. Tundra be dammed: beaver colonization of the Arctic. Glob. Change Biol. 24: 4478-4488. doi:10.1111/ gcb.14332.

Tape, K.D., Gustine, D.D., Reuss, R.W., Adams, L.G., and Clark, J.A. 2016. Range expansion of moose in arctic Alaska linked to warming and increased shrub habitat. PLoS One, 11: e0152636. doi:10.1371/journal.pone.0152636.

THTC (Tuktoyaktuk Hunters and Trappers Committee), Tuktoyaktuk Community Corporation, The Wildlife Management Advisory Council (NWT), The Fisheries Joint Management Committee, and the Joint Secretariat. 2016. Tuktoyaktuk Community Conservation Plan: Tuktuuyaqtuum Angalatchivingit Niryutinik. Tuktoyaktuk, NWT. Available from https://static1. squarespace.com/static/5e2093a7fd6f455447254aff/t/5e262a8ae3c0a94c0a8ffa4a/ 1579559611016/2016-Tuktoyaktuk-Community-Conservation-Plan-R.pdf.

Turner, N.J., Ignace, M.B., and Ignace, R. 2000. Traditional ecological knowledge and wisdom of Aboriginal peoples in British Columbia. Ecol. Appl. 10(5): 1275-1287. doi:10.1890/1051-0761(2000)010[1275:TEKAWO]2.0.CO;2.

Usher, P.J. 2002. Inuvialuit use of the Beaufort Sea and its resources, 19602000. Arctic, 55(5): 18-28. doi:10.14430/arctic732.

Walsh, J.E., Overland, J.E., Groisman, P.Y., and Rudolf, B. 2011. Ongoing climate change in the Arctic. Ambio, 40(1): 6-16. doi:10.1007/s13280-011-0211-z.

Waples, R.S., Pess, G.R., and Beechie, T. 2008. Evolutionary history of Pacific salmon in dynamic environments. Evol. Appl. 1(2): 189-206. doi:10.1111/ j.1752-4571.2008.00023.x. PMID:25567626.

Welch, D., Ishida, Y., and Nagasawa, K. 1998. Thermal limits and ocean migrations of sockeye salmon (Oncorhynchus nerka). Can. J. Fish. Aquat. Sci. 55(4): 937-948. doi:10.1139/f98-023.

Wesche, S.D., and Chan, H.M. 2011. Adapting to the Impacts of Climate Change on Food Security among Inuit in the Western Canadian Arctic. EcoHealth, 7(3): 361-373. doi:10.1007/s10393-010-0344-8.

Wenzel, G.W. 1999. Traditional ecological knowledge and Inuit: reflections on TEK research and ethics. Arctic, 52(2): 113-124. doi:10.14430/arctic916.

Wipfli, M.S., Hudson, J.P., Caouette, J.P., and Chaloner, D.T. 2003. Marine subsidies in freshwater ecosystems: salmon carcasses increase the growth rates of stream-resident salmonids. Trans. Am. Fish. Soc. 132(2): 371-381. doi:10.1577| 1548-8659(2003)132<0371:MSIFES > 2.0.CO;2.

Yoon, S., Watanabe, E., Ueno, H., and Kishi, M.J. 2015. Potential habitat for chum salmon (Oncorhynchus keta) in the Western Arctic based on a bioenergetics model coupled with a three-dimensional lower trophic ecosystem model. Prog. Oceanogr. 131: 146-158. doi:10.1016/j.pocean.2014. 12.009 . 


\section{Appendix A. Interview questions investigating changes in environmental conditions, Pacific salmon harvest, and local fish species}

\section{Questions on environmental conditions}

- What is your name, age, and where do you live?

- Do you travel on the water regularly?

- If so, how many days per week or month?

- Do you travel on rivers or on the ocean or both?

- Where do you usually travel? Can you show me on a map? (or Google Earth)

- Are the rivers or the coastal environment where you usually travel the same or different than $10,20,30$, or 40 years ago?

- If different, what has changed?

- If different, when did you notice these changes? (What year, time of year, or season?)

$\square$ Sometimes it can help to use other points of reference here (such as the age of their kids or grandkids, or which boat and outboard motor they were operating).

- Can you show me on a map any locations that have changed?

- Are there any environmental changes you have noticed that you think are affecting rivers, lakes, or the ocean near the coast?

- If so, what changes have you observed?

- If so, when did you notice these changes? (What year, time of year, or season?)

- Can you show me on a map where you have noticed these changes?

- Are there any changes to the rivers, lakes, or coastal areas where you travel that have affected where or how you can travel?

- If so, what changes have you observed?

- If so, are there any areas that you can not travel anymore that you used to be able to?

- If so, when did you notice these changes? (What year, time of year, or season?)

- Can you show me on a map these locations?

- Have you noticed any changes in the water levels of the rivers and lakes you travel on?

- If so, what changes have you observed?

- If so, when did you notice these changes? (What year, time of year, or season?)

- Can you show me on a map where you have noticed these changes?

- Have you noticed any changes to rivers, lakes, or coastal areas like sand bars, erosion, changes to cut banks, water quality, vegetation, water flow?

- If so, what have you noticed?

- If so, when did you notice these changes? (What year, time of year, or season?)

- Can you show me on a map where you have seen these changes?

- Throughout your life, would rivers, lakes, or coastal areas (water levels, colour, sand bars) often or sometimes change?

$\circ$ Or, are any changes you have noticed unlike conditions you have seen before (i.e., unprecedented)?
- If you have noticed any changes in the rivers, lakes, or coastal areas, how do you feel about these changes? (If the participant asks for clarification, the interviewer can provide example feelings, such as concern, surprise, lack of concern, or welcoming the changes.)

- If you have noticed changes in rivers, lakes, or coastal areas, are the changes affecting your access to fish camps and other fishing locations?

- If so, can you show me these locations on a map?

- If you have noticed changes in rivers, lakes, or coastal areas, are these changes affecting any fish you harvest?

$\circ$ If so, which species?

- Can you show us on a map locations where you have caught species that are impacted?

- If you have noticed any changes in rivers, lakes, or coastal areas, why do you think these changes may be happening?

- How do you think that rivers, lakes, and coastal areas in the ISR should be cared for in the future?

- Over the time that you have been fishing, have environmental conditions changed?

- Have you noticed changes to the water, ice, or bottom habitats?

$\square$ Timing of ice-on, ice-off

$\square$ Amount and timing of snow

$\square$ Overflow, winter stream flow - location and timing

Water temperature

- Turbidity (timing, duration, location)

Ocean conditions (e.g., waves)

$\circ$ Have you noticed changes to the weather?

$\square$ Types and frequency of weather events (e.g., high winds, storms)

$\square$ Wind (timing of shifts in wind direction?)

$\square$ Air temperature

- Have you observed connections between changes in the environment and the types of fish and prey that you see?

- E.g., do the fish or prey communities change depending on prevailing winds or ice conditions?

- Any examples of strange weather being associated with fish behavior or fish catches? Anything you remember hearing from your parents or grandparents?

\section{Questions on Pacific salmon}

- Do you fish in the ISR?

- If so, how many times per week or per month?

- Do you fish in the rivers or in the coastal environment?

- Can you show us on a map where you fish? (You do not have to.)

- Did you grow up fishing? How old were you when you learned how?

- When you go fishing, do you catch salmon?

- If so, do you know what kinds of salmon you catch? Has this changed through your lifetime? When did this change occur?

$\square$ Sometimes it can help to use other points of reference here (such as the age of their kids or grandkids, or which boat and outboard motor they were operating). 
- If so, when have you caught salmon before? (year and season)

- If so, would you use them in the past? How?

- Would you use them if you catch them now or in the future? How?

- If not, do you know what you could use them for?

- Can you show us on a map where you have caught them?

- What is the body condition of the salmon you caught?

$\square \quad$ Are they silver or colourful?

$\square$ Were the salmon ready to spawn?

$\square$ Are the eggs ripe - if you run your fingers along their bellies do eggs come out?

- Did your parents or grandparents talk about catching salmon? How often and when?

- Have you noticed a change in the amount of salmon you catch when you fish?

- If so, when did you notice this change? (what boat were you using, what year)

- If so, how many salmon did you catch in a week or month of fishing before you noticed this change? How many salmon per week or month would you catch after you noticed this change?

- What time of year or what season do you start catching salmon in your net?

○ How long after break-up?

- Has this gotten later, earlier, or unchanged?

- Can you show me on a map where you were fishing when you first observed salmon or caught them in your net?

- Have your fishing practices changed through time? (i.e., harvest locations, mesh size, using gillnets or jigging or other methods)

- If so, what year did these changes occur? Or how old were you? (see previous reference points)

- When you catch salmon, do you catch any other fish in the net?

- If so, what kinds of fish do you catch with salmon?

$\square$ Consult salmon booklets so participants can visualize the different types

- If so, how many salmon do you catch in a net and how many other species of fish do you catch in the net? (i.e., for every salmon, how many other fish are there in the net?)

- When you catch salmon, do you see signs that they are eating or not? (i.e., full stomachs, do they look like they are eating, are they in places where other fish are eating?)
- Do you catch salmon when fishing on rivers, lakes, or the ocean?

- Can you show us these locations on a map? (It is ok if they don't want to disclose.)

- What equipment do you catch salmon with? (i.e., gill net, hook, line, etc.)

- Do you catch salmon on windy or calm days or both? Do you know what direction the wind usually is when you catch salmon?

- Does the amount of rain change the chances of catching salmon?

- Do you catch salmon when you fish under the ice? In rivers, lakes or on the ocean? Nearshore or away from shore?

\section{Questions on native fish}

- What kinds of fish do you normally catch in your subsistence fishing activities?

- Have you noticed changes in the amount of fish that you catch or see?

- If so, are some kinds of fish increasing, while others are decreasing in abundance?

- When did these changes happen?

- Have you noticed changes in the types of species that you catch or see?

- How has the fish community changed?

- When did these changes happen?

- Do you see the same species each year, or do the types of species you see vary by year?

- Have you noticed changes in the types of prey that fish are eating?

- How has the prey community changed?

-When did these changes happen?

$\circ$ Do you see the same prey each year, or does the types of prey you see vary by year?

- Have you noticed changes in the types of prey that marine mammals are eating?

- What kinds of marine mammals are showing these changes in diet? (e.g., seal, whale)

- How has the diet changed for these marine mammals?

-When did these changes happen?

- Do you see the same prey each year, or does the types of prey you see vary by year?

\section{Closing questions}

- Is there anything else you think we should know or that you would like to tell us, or other important locations we should note on the map? 


\section{Appendix B}

Table B1. Codes used for thematic interview analysis.

\begin{tabular}{|c|c|c|}
\hline Salmon & Environmental change & Experience \\
\hline Catch location & Affecting travel & How long have they been fishing \\
\hline Lake & Air temperatures & How often they fish \\
\hline Ocean & Causes of change & Target fish \\
\hline River & Climate change & Typical fishing methods \\
\hline Catch method & Development & Gill net \\
\hline Jigging & Earth's axis & Jigging \\
\hline Netting & Effects on fish or fishing & Rod and reel \\
\hline Rod and reel & Aklavik effects on fish(ing) & When they fish \\
\hline Change & Inuvik effects on fish(ing) & Open water \\
\hline Decrease & Paulatuk effects on fish(ing) & Under ice \\
\hline Increase & Sachs effects on fish(ing) & Where they fish \\
\hline Neutral & Tuktoyaktuk effects on fish(ing) & Darnley Bay East \\
\hline Changing salmon harvest time & Ulu effects on fish(ing) & Darnley Bay West \\
\hline Conditions influencing salmon & Erosion & Eileen Jacobson Bush Camp \\
\hline Cultural use & Feelings & Hornaday River \\
\hline Consumption & Historical changes & Husky lakes \\
\hline Discarded & Ice cover & Inuvik - lakes \\
\hline Distribution & Ocean conditions & Mackenzie Delta East \\
\hline Dogs & Permafrost associated changes & Mackenzie Delta West \\
\hline Salmon program & Sand bars & Outer Delta - ocean \\
\hline Estimated catch over lifetime & Snow & Paulatuk Harbour \\
\hline First catch & Strange phenomena & Paulatuk lakes \\
\hline Fish condition & Timing of environmental events & Sachs Harbour \\
\hline Eggs or milt & Vegetation & Sachs lakes \\
\hline Healthy & Water levels & Sachs River \\
\hline Sick & Lakes & Shingle \\
\hline Parasites & Ocean & Tuktoyaktuk Harbour \\
\hline Skinny & Rivers & Ulukhaktok — lakes \\
\hline Soft & Water quality & Ulukhaktok - ocean \\
\hline Silver & Water temperatures & \\
\hline Spawning & Weather & Fishing opportunity \\
\hline Interactions with other fish & What to do & Cultural \\
\hline Never caught a salmon & & Cultural change \\
\hline Parents or elders caught salmon? & Local fish & Fish culture \\
\hline Maybe & Diet & Resilience \\
\hline No & Fish health & Stories \\
\hline Yes & General changes & \\
\hline Species ID & Predation & Mammals \\
\hline Chinook & Species & Beavers \\
\hline Chum & Cod & Caribou \\
\hline Coho & Coney & Muskox \\
\hline Pink & Dolly Varden & Muskrats \\
\hline Sockeye & Herring & Otters \\
\hline Target fishes & Jackfish & Seals \\
\hline Time of catch & Land-locked char & Whales \\
\hline Approximate year & Loche & \\
\hline $2000 s$ & Ocean char & \\
\hline 2010s & Sandlance & \\
\hline 2019 & Trout & \\
\hline $1960 \mathrm{~s}$ & Whitefish & \\
\hline $1970 s$ & Weather effects & \\
\hline \multicolumn{3}{|l|}{ 1980s } \\
\hline \multicolumn{3}{|l|}{ 1990s } \\
\hline \multicolumn{3}{|l|}{ Open water } \\
\hline \multicolumn{3}{|l|}{ Under ice } \\
\hline Weather of catch & & \\
\hline
\end{tabular}

Note: Thematic categories are bolded, and indentation reflects the structure of codes and subcodes. 